\title{
Understanding Effectiveness of International Sanctions
}

Thomas Biersteker

Graduate Institute of International and Development Studies (IHEID) in Geneva

\begin{abstract}
Thomas Biersteker took part in 2019 Gerda Henkel Forum: Values and Interests in Communication Between Russia and The West held in MGIMO-University in late April this year and on the margins of the Forum he was kind enough to give an interview to our editor Vadim Belenkov on effectiveness of targeted international sanctions. Professor Biersteker is a renowned expert on this issue, he co-edited a book «Targeted Sanctions» recently published by Cambridge University Press. The interview shows that targeted sanctions involve restrictive measures against a narrowly-defined range of individuals and firms. Professor Biersteker explained in detail the difference between sanctions with the purpose of coercion, constraining and signaling. He reaffirmed his claim that effectiveness of sanctions should be studied separately for each type of purposes. In the interview professor Biersteker updated some of the findings published in his book three years ago. In 2016 constraining and signaling sanctions were effective at the same level, $27 \%$ of the time. Today data reveal that effective constraining fell by $4 \%$ points and effective signaling rose by $2 \%$ points. Effectiveness of coercion remains at $10 \%$. The average effectiveness of sanctions across three types is about $20 \%$. Taking into consideration the difficulty of conflicts and issues over which sanctions are applied - North Korea's nuclear program, Iran's potential development of nuclear weapon program, ethnic and religious conflicts in Africa, the Middle East $20 \%$ should not be considered a small figure. Biersteker also reaffirmed the «sanctions paradox» found in 1999 by Daniel Drezner that very often the countries against which sanctions would be most likely effective are those that are most interdependent whereas sanctions are usually applied in situations when they are less likely to be effective.
\end{abstract}

Key words: targeted sanctions, comprehensive sanctions, purposes of sanctions, coercion, constraining, signaling, effectiveness, interdependence.

Vadim Belenkov (V.B.). Good afternoon, Professor Biersteker! We are very proud that you have agreed to give an interview for our journal MGIMO Review of International Relations. There are a lot of topics which we can discuss, but primarily we are interested in your recent research on targeted sanctions. In your book [1] 
and articles [2] you contrast them with comprehensive sanctions. Could you explain to our readers the difference between these types of sanctions?

Thomas Biersteker (Th.B.). The principal difference is that comprehensive sanctions are broad-based trade and financial embargoes on an entire country, an entire population. Targeted sanctions, by contrast, consist of a large range of different types of restrictive measures, but they can be very narrowly targeted at the individual, individual firm or, perhaps, on some certain types of practices, for example, like an arms embargo or restrictions on diplomatic practices. They can also be targeted at individual sectors of the economy. So targeted sanctions are qualitatively different from comprehensive sanctions particularly in terms of the scope of their impact or their degree of discrimination on a civilian population. One of the important differences between comprehensive and targeted sanctions is that targeted sanctions are more readily adaptable. If there is a change in relations between the sender and the target, or a change of the situation in the conflict, you could ratchet them up or ratchet them down. You could increase the scope of the sanctions or decrease the scope. Comprehensive sanctions are a much blunter instrument. Once you start to move toward relaxation, it is often viewed as a sign of weakness, lack of will, or commitment. And therefore, they are less adaptable as an instrument. This is one of the arguments for targeted sanctions. Not only do they not affect the entire population indiscriminately, but they also can be more useful if they are adopted in a conflict situation.

V.B. So not only targeted sanctions are more justifiable from moral grounds, but also they are likely to be more efficient than comprehensive sanctions?

Th.B. Yes, but they may be not more efficient per se, but more adaptable. You can change them depending on the situation. For example, you could offer sanctions relaxation as a gesture if you are trying to break a diplomatic logjam or blockage in negotiations. You could offer partial sanctions relief as a way of breaking a deadlock in negotiations. They have maybe not greater efficiency, but greater utility in this way.

V.B. And in contrast, targeted sanctions may be strengthened incrementally. Is this true?

Th.B. Yes, that's right. They can be relaxed, or they could be strengthened gradually, incrementally in the event there is no response, if there is no movement in terms of desired goals of the application of sanctions in the first place.

V.B. Political elites may respond to targeted sanctions by transferring the costs of sanctions to the whole society thus transforming targeted sanctions into comprehensive ones. Is there then a sense in dividing sanctions into targeted and comprehensive ones?

Th.B. Well, it is often difficult. Targeted sanctions are used politically by targeted elites to say that this is an attack on all of us, not just on a small percentage of the population. When we get into the politics of sanctions in targeted countries, we see that it is not unusual for targeted elites to translate them in political terms domestically in terms of something that is applied to all of the population. But this variation in the degree of targeted sanctions measures matters. Some are so narrowly targeted on just a handful of 
individuals that they really cannot translate the costs to the larger population. Perhaps, they can translate costs to the immediate people who work for them or to the firms or the people who are immediately in their sphere of influence, but they cannot really translate the costs onto the larger population. However, the broader sanctions become, the less discriminating they become, the more it is possible particularly for authoritarian leaders to transfer the costs onto the general public. This is well-established in the case of comprehensive sanctions, but when targeted measures become so broad that they begin to approximate and to be close to comprehensive measures, this increases prospects that elites will transfer the costs to the most vulnerable parts of the population in their countries. This is what happened in Iraq. Saddam Hussein used comprehensive sanctions to offer incentives to his strong supporters in the Sunni part of Iraq and to have the Shia population in the south-east of Iraq to bear the major costs of sanctions. This is what authoritarian governments can do to distribute the burden to certain populations and sometimes with long-lasting political consequences.

V.B. Can we say that the difference between targeted and comprehensive sanctions is in the degree of discrimination and that there is a continuum on one side of which we have sanctions which are intended to target only particular individuals (politicians and businessmen) and on the other side we have comprehensive sanctions such as total trade embargoes? And can we say that there are some measures in between such as restrictions on financial transactions of some banks?

Th.B. Yes, absolutely. And in fact in our most recent research we have created a scale of degrees of discrimination of combinations of United Nations sanctions measures. I specialize mostly on UN sanctions, though I have studied EU and other sanctions as well. And US sanctions to some extent. But with UN sanctions, we have come up with a 6-point scale. In fact we have a 7-point scale because 1 in the continuum are sanctions which are authorized, but not applied. For example, in the case of Mali, until last December there was a resolution, sanctions were authorized by the UN, but nobody was designated, nobody was listed. So we have a legal application of sanctions, but they were not applied to individuals. This is the lowest category on the continuum because this does not have much of an impact. It does because there is a threat, but we do not know the outcome. Then we have just individual measures, category 2. Next, we have arms embargoes, diplomatic restrictions, or category 3 . Then we go to sectoral sanctions. For us, sanctions of category 4 would involve financial sector measures, or the designation of the central bank. If it refers to the institution so central to the entire financial system that makes it category 4 . If there is an oil embargo since it affects energy and everyone in the country directly or indirectly, these are also category 4 . And then we have right now a fairly exceptional case with North Korea, the DPRK. And in the case of DPRK the list of sanctions is so broad that it is hard to define sectors which are not sanctioned right now. There are a few, so technically sanctions against DPRK are targeted, but they are very close to comprehensive sanctions.

We have this sanction discrimination scale and when we look over time we see some interesting developments. For example, the United Nations before the end of 
the Cold War only applied sanctions twice: on white minority regimes in Southern Rhodesia and South Africa. Sanctions on Rhodesia were comprehensive, sanctions on South Africa were targeted at the UN level, restricted to an arms embargo. During the 1990s, however, after the end of the Cold War what colleagues George Lopez and David Cortright called «the sanctions decade» [3], there was a major increase in the number of UN sanctions being applied. In the 1990s, the United Nations applied fairly broad measures. They applied restrictions on oil in a number of cases (in Angola, in Sierra Leone, Haiti). These are all category 4 sanctions. They also applied broad financial restrictive measures. During the first decade of this century, however, all UN targeted sanctions fell to levels 1,2 or 3 , which is much lower on our continuum. That was really a decade of genuine targeted sanctions. And it really follows the way of sanction reform efforts by the governments of Switzerland, Sweden and Germany to develop this instrument from 1998 through 2003. But we see a gradual decrease of discrimination in sanctions starting with sanctions on Libya in 2011, but now quite dramatically, since 2016 with the sanctions on North Korea, we see the return to quite broad-reaching sanctions applied by the United Nations. Again, DPRK today is the exception. Many of the new sanctions regimes (Yemen, South Sudan, Mali) are veryvery narrowly targeted ( 3 people, 5 people, 6 people). They are very targeted relative to DPRK sanctions regime.

V.B. We have discussed the difference between these types of sanctions. But sanctions are costly not only for targets of sanctions, but also for senders, the countries and organizations which apply sanctions. Which type of sanction is less costly to elaborate and apply for such countries and organizations? And why?

Th.B. Well, it involves a calculation. It is a very important point. What differentiates the application of sanctions from diplomatic critique, protest or complaint in public diplomacy is that you are backing your concerns, your statement, with measures that are intended to affect the target, to hurt the target in a certain way, and at the same time to be costly in some way to the sender. With the application of sanctions, you also show your conviction, because you are saying that you feel so strongly about the issue, that you are ready to impose costs on yourself. Anytime you apply sanctions, you are restricting opportunities for your nationals to do business, to conduct trade, to have normal relationships with targeted countries. As a result, you are signaling the strength of your resolve about the issue. For example, we can talk about the case of EU sanctions on Russia which have been costly for European firms, particularly in the short term. They were costly, but they were applied nonetheless, even though they were not cost-free for Europe. And in the design of sanctions there is, up to a certain level, a degree of strategic discussion, calculation of how broad, how narrow sanctions should be, of who should be designated, of what should be the argument and rationale for their application. There is a certain degree of strategy and calibration, but this becomes more complicated when we are dealing with sanctions being applied by multilateral organizations. UN sanctions, or EU sanctions involve a more complicated process of determining of who and what is to be sanctioned, whereas when an individual country 
decides to apply restrictive measures as, frankly speaking, many countries do, then it is an instrument of foreign policy. In theory, it is relatively easier for an individual country to be strategic than multilateral organizations, since the latter entail negotiation at the UN, the EU or the AU level. I should include AU sanctions, since the African Union also applies sanctions on a regular basis.

\section{V.B. In your research you claim that it is necessary to account for different pur- poses of sanctions in order to correctly assess their effectiveness. You enumerate three types of purposes: coercion, constraining and signaling. What is the differ- ence in means and mechanisms between sanctions applied with purposes of coer- cion, constraining and signaling?}

Th.B. First, it is important to point out that it is fairly common that there are multiple purposes being applied simultaneously. Sanctioning parties are trying not to just coerce, just constrain or just signal. It depends very much on the context. Most of the literature, I would say, most of the public discourse about sanctions, focuses on their capacity to coerce a change in behavior. That is the standard, the popular, understanding of the purpose of sanctions. And, of course, this is the principal objective in the majority of instances of the application of UN sanctions at least.

But there are some situations in which it is not really possible to coerce a change in behavior because you are not involved in any negotiations with potential targets. Sanctions applied against groups engaged in the commitment of acts of terrorism are an example here. In this case, there is no negotiation underway. There might be a desire that people would give up their normative cause, but those with the strong belief in the creation of global Caliphate are not going to be the subject of negotiations. Therefore, sanctions are designed (particularly, I am referring to the sanctions on Al-Qaida and on ISIS) to constrain. They are not intended to change behavior, they are intended to raise the costs and make it more difficult for groups committing acts of terrorism to move finances across borders, to use formal sector financial institutions. These sanctions are fundamentally constraining ones.

The third type, signaling, is, I would argue, present in all sanctions. There is always a normative signal being sent. If you read the text of resolutions or examine closely what the Security Council has decided, you can discern that it is sending a normative signal about behavior. It may be an attempt to criticize this behavior, to reinforce an existing norm and to signal not just the target, but also to others. Sanctions are a public statement. In this sense it is what I call a normative signal. I would say that all UN sanctions are engaged in application of normative signal. Often there is more than one norm being signaled. And the degree of clarity varies. But these are all purposes. In a sense they have different logics. The logic of coercion is different from the logic of constraint or signaling because there is a different theory behind what you actually want to accomplish with the different purposes. Many people think of sanctions as punishments. In a sense they are. Sanctions are a form of public punishment, but it is actually a way of raising cost to the target and, perhaps, persuade the target to change its behavior. In constraining sanctions there is no logic of changing behavior: it is basically cutting sources of finance, sources of support. With re- 
gard to signaling, it is more of a logic of public communication, strategic communication in that you are trying to send a signal both to a target or to a larger community.

V.B. As I understand, constraining means disabling a target of an opportunity to engage in proscribed activities while coercion means changing the system of incentives for the target so that it voluntarily stops its engagement in proscribed activities. Is it correct?

Th.B. I suppose that the ideal of coercion is that you have sent demands to the target and the target accedes to those demands, changes its behavior. But that does not happen very often. We estimated that this happens only 10 percent of the time with regard to UN sanctions. Changing behavior is very difficult. And this is consistent with findings on warfare in, for example, Robert Pape's work on aerial bombing, the limited effects of bombing on changing behavior [5]. This is a very low probability outcome. Constraining means raising the costs or forcing a change of strategy. The target is not going to change its behavior; it is not changing its behavior. But this behavior is made costlier, more difficult. The target has to change strategy and the new strategy might actually be less effective. Constraining is aimed at degrading capacity. As for signaling, it is occasionally, but actually rarely the most important objective of sanctions. But this is always a subjective interpretation, and I must concede that when it comes to interpreting EU Council decisions or UN Security Council resolutions, we are exposed to applying rational criteria when we know that a political process of compromise, bargaining and agreement is underway. It may not be amenable to interpretation in terms of consistent rationale. We try to say what we see from our reading of the resolutions and our reading of discussions around the crafting of resolutions from various sources what the intention or primary intention was.

V.B. We have just talked about your findings that sanctions with the purpose of constraining and signaling are more efficient than sanctions with coercive purpose.

Th.B. Not efficient, we argue that they are more effective. Efficiency would have to deal with how much you expended in the way of resources and how effectively you did it. This is an important technical difference between effectiveness and efficiency. We were talking about levels of effectiveness. In some ways, it is not that surprising, I suppose. Coercing somebody to change behavior is likely to be more difficult than constraining. And one would think that sending a signal would be relatively easier. One of our surprising findings is that although constraining and signaling were effective at the same level, $27 \%$ of the time when we published our book on UN sanctions in 2016, in some recent updates of our Sanctions App, effective constraining fell to $23 \%$ and effective signaling rose to $29 \%$. There is a slight adjustment of numbers. Effectiveness of coercion remains at $10 \%$. This is not a significant change, just updating results presented in the book.

Every year we meet and recode or update all the ongoing cases for inclusion in Sanctions App, which we developed to disseminate our research. There is now 15 ongoing UN Security Council sanctions regimes in place. That means that we reevaluate the numbers every year. And the last year of such a reevaluation was 2018. 
V.B. Although sanctions with the purpose of constraining and signaling are more effective than sanctions with the purpose of coercion, in general sanctions are effective in less than a half of cases. Why in your opinion do sanctions work so poorly?

Th.B. The average effectiveness of sanctions across three types is about $20 \%$. And $20 \%$ is not such a bad figure. If you think about the conflicts over which sanctions are applied, these are the most difficult and intractable conflicts in the world. We are talking about North Korea's nuclear program, we are talking about Iran's potential development of nuclear weapon program, we are talking about ethnic, religious conflicts in Africa, the Middle East, we are talking about other ongoing civil wars. These are not easy situations, so we have what is called «selection bias». We are dealing with the most difficult and intractable cases. The numbers do not bother me as much as they bother some. Sanctions are ineffective because conflicts to which they are being applied are so difficult. A second explanation for low levels of effectiveness is that in many cases there is a relative ease of evasion of sanction measures. Anytime sanctions or restrictive measures are applied you immediately create a very powerful incentive for individuals who are able to evade those measures. That means that they create opportunities for extraordinary profit if you can get away with it. People are infinitely creative, and they are finding ways around and creating second firms, using other devices that clever people are capable of developing. We have to accept the fact that sanctions whenever applied instantly create a powerful incentive to figure out the ways to get around them. And very often a relatively very quick adaptation of individuals and markets occurs, but it depends very much on the design of the specific measures. It is hard to generalize beyond that. A very significant factor I would argue in terms of sanctions effectiveness is related not just to the challenge of the conflicts to which they are applied, but to the degree of coherence and political resolve among the sending parties. With regard to the UN Security Council, we find the strongest set of agreement among its members, particularly among the permanent members of the Council is around threats of terrorism. There is a very strong consensus on that. All permanent members of the Council face threats from the same source in essence. There is a very strong political resolve to counter terrorism. In fact, it is the most heavily resourced committee, monitoring team, effort, with political will and a willingness to apply and implement measures in this domain. Proliferation is second to that. We find that also in terms of investment and resources. Again, this concerns the consensus among the permanent members of the Council that additional proliferation of nuclear weapons is not a good thing. And they invest heavily in the resources provided to this area. When there is strong political will, we are likely to see greater enforcement. It is when there is a disagreement or agreement that sanctions should be applied, but no interest of implementation, that is when they become in fact less effective. And we have a number of cases where that is the case, where there is a bargaining, negotiation, reluctant consensus, abstention. And we look at all these factors. There is a question what political will is. What does it mean? Often it is a tautology. People say that sanctions were effective because there was political will. And because there was political will, they were effective. This is just 
a circling argument. But in fact, now we can measure what the vote was, whether there were any reservations, any abstentions. And then we use that to say what the indication of the amount of political will on certain resolution is. We have some ways in which we can gauge that.

V.B. Not long time ago practically everyone talked about the growing interdependence among states, primarily economic interdependence. Does interdependence make sanctions less effective?

Th.B. No. Actually, greater degrees of interdependence are likely to make sanctions more effective. This is what Daniel Drezner was referring to when he talked about the «sanctions paradox»[4], that very often the countries against which they would be most likely effective are those that are most interdependent whereas they are typically applied in situations when sanctions are less likely to be effective: cases like North Korea, which is a very insular state and relatively disconnected to the rest of the global economy. The North Korean sanctions are being applied to the least likely case or situation. One would expect them to work less in that it has a history of pursuing the strategy or policy of Juche which is self-reliance or self-reliant development. North Korea has proven to be relatively more resilient than many other economies. Degrees of interdependence should actually create greater effectiveness. But again, it all depends on whether or not there is a sufficient political resolve because as we discussed earlier, sanctions imply costs not just on a target, but to the sender as well.

V.B. It is easier for the sender to create credible signals when there is more interdependence because interdependence makes sanctions costlier for senders. Is this correct?

Th.B. Exactly right. But in many instances, the cost of application of sanctions is very asymmetrical. Countries and multilateral organizations which apply sanctions often share costs among themselves. You are right that the signal of resolve is greater but in fact asymmetry is prevalent in most cases. The target country can do very little to equally damage the sending country and that is why frankly, the Russian sanctions are so interesting. They are interesting if we just look at the EU and Russia because each party has the capacity to affect the other, whereas Iran had very limited things it could do in response to the EU expansion of its sanctions on Iran in 2010-2012 and 2012 onward. At the same time in the case of Russia, the countermeasures applied by Russia were more effective than most EU sanctions applied to other parts of the world. The degree of interdependence between the EU and Russia is higher than the degree of interdependence between EU and most other targets of EU sanctions.

V.B. Unfortunately, we are running out of time. Thank you for the very interesting interview. And I think it will be interesting and useful for readers of our journal. I hope this interview will help them better understand sanctions.

Th.B. Let me conclude by making one point. Very few people like sanctions. I would not say that I like sanctions. But sanctions are very much misunderstood. That is why it is important to get a better understanding of why they are applied, how they work. Not just do they work, but how do they interact with other instruments to affect 
the outcome in different situations. I am pleased to make a small contribution to this discussion and thank you for reading my book.

\title{
References:
}

1. Biersteker T. J., Eckert S. E., Tourinho M. (ed.). Targeted sanctions: The impacts and effectiveness of United Nations action. Cambridge: Cambridge University Press, 2016. 422 p.

2. Biersteker T. J. et al. UN targeted sanctions datasets (1991-2013). Journal of Peace Research. 2018, vol. 55, no. 3, pp. 404-412.

3. Cortright D. et al. The sanctions decade: assessing
UN strategies in the 1990s. Boulder, CO: Lynne Rienner Publishers, 2000. 274 p.

4. Drezner D. W. et al. The sanctions paradox: Economic statecraft and international relations. Cambridge: Cambridge University Press, 1999. 364 p.

5. Pape R. Bombing to win: Air power and coercion in War. Ithaca: Cornell University Press, 1996. $408 \mathrm{p}$.

\section{About the author:}

Thomas J. Biersteker - Professor at the Graduate Institute of International and Development Studies, Maison de la Paix, Chemin Eugène-Rigot 2, 1202 Genève. E-mail: thomas.biersteker@graduateinstitute.ch.

\section{Понимание эффективности международных санкций}

\author{
Томас Бирстекер \\ DOI 10.24833/2071-8160-2019-3-66-7-16
}

\section{Женевский институт международных отношений и развития}

Томас Бирстекер принял участие в форуме «Ценности и интересы в коммуникации между Россией и Западом», который состоялся в апреле этого года в МГИМО при поддержке фонда Герды Хенкель. На полях этого форума он любезно согласился дать интервью об эффективности точечных санкций редактору нашего журнала Вадиму Беленкову. Томас Бирстекер - признанный специалист в этом вопросе, соавтор монографии «Точечные санкции», недавно опубликованной издательством Cambridge University Press. В интервью рассказывается, что точечные санкции подразумевают ограничительные меры, направленные против узкого круга людей и фирм. Профессор Бирстекер подробно объяснил разницу между санкциями с целью принуждения, санкциями с целью сдерживания и санкциями с целью подачи сигнала. Он повторил своё утверждение, что эффективность санкций должна изучаться раздельно в зависимости от их цели. В интервью профессор Бирстекер привёл обновлённые результаты своих исследований эффективности санкций по сравнению с результатами, продемонстрированными в опубликованной им три года назад книге. Согласно данным, представленным в 2016 г., санкции с целью сдерживания и подачи сигнала были одинаково эффективными, в 27 \% эпизодов их применения. К настоящему времени данные показывают, что эффективность сдерживания упала на 4 \% пункта, а эффективность подачи сигнала выросла на 2 \% пункта. Санкции с целью принуждения были и остаются эффективными в $10 \%$ эпизодов их применения. В среднем санкции всех трех типов были эффективны в 20 \% случаев их использования. $20 \%$ - немаленькое число, если учесть сложность 
конфликтов и вопросов, в связи с которыми применяются санкции: ядерная программа Северной Кореи, потенциальное развитие ядерной программы Ирана, этнические и религиозные конфликты в Африке и на Ближнем Востоке. Т. Бирстекер также подтвердил существование «парадокса санкций», который был обнаружен Дэниэлом Дрезнером в 1999 г. Этот парадокс заключается в том, что санкции эффективнее применять в ситуации высокой, но асимметричной взаимозависимости, однако их чаще всего применяют против стран с низким уровнем взаимозависимости, делая санкции заведомо неэффективными.

Ключевые слова: санкции, точечные санкции, всеобъемлющие санкции, цели санкций, принуждение, сдерживание, подача сигнала, эффективность, взаимозависимость.

\section{Список литературы:}

1. Biersteker T. J., Eckert S. E., Tourinho M. (ed.). Targeted sanctions: The impacts and effectiveness of United nations action. Cambridge: Cambridge University Press, 2016. 442 p.

2. Biersteker T. J. et al. UN targeted sanctions datasets (1991-2013) // Journal of Peace Research. 2018. Vol. 55. №. 3. Pp. 404-412.

3. Cortright D. et al. The sanctions decade: assessing UN strategies in the 1990s. Boulder, CO: Lynne Rienner Publishers, 2000.274 p.

4. Drezner D. W. et al. The sanctions paradox: Economic statecraft and international relations. Cambridge: Cambridge University Press, 1999. 364 p.

5. Pape R. Bombing to win: Air power and coercion in War. Ithaca: Cornell University Press, 1996. 408 p.

\section{Об авторе:}

Томас Бирстекер - профессор Женевского института международных отношений. Maison de la Paix, Chemin Eugène-Rigot 2, 1202 Genève.

E-mail: thomas.biersteker@graduateinstitute.ch. 